\title{
Performance testing of the rotary paddy weeder with different angle of blade
}

\section{ANISA AND GEETA}

Received : 08.02.2017; Revised : 01.03.2017; Accepted : 13.03.2017

See end of the Paper for authors' affiliation

Correspondence to :

ANISA

Department of Farm Machinery and Power Engineering, Vaugh School of Agricultural Engineering and Technology, Sam

Higginbottom Institute of Agriculture,ALLAHABAD (U.P.) INDIA

Email : anisa0987@gmail.com
-ABSTRACT : Rice (Oryza sativa L.) is an important crop which is being cultivated most extensively through the world and is considered as staple food crop of more than 60 per cent of world's population. In India weed control is one of the major problems in rice cultivation according for a major share in the cost of cultivation. About 60 per cent of the cost of cultivation of the Kharif crops goes in weed control alone. The cost of weeding can be substantially reduce by Introducing improve weeding tools. Six serrated blades were fixed on bush drum, shaft of diameter $2.5 \mathrm{~cm}$ with axle of $1.1 \mathrm{~cm}$ diameter. The blades was fixed with three different angels on the bush drum in different weeder, was $10^{\circ}, 15^{\circ}$ and straight. Its performance was compared with conventional manual weeding. Using it in wet field condition the field capacity of 80 to 85 per cent during the operation. It was found that weeder with straight blade angles gave highest weeding efficiency other than two weeding methods.

- KEY WORDS : Rotary weeder, Paddy weeder, Weed management, Intercultural tool

- HOW TO CITE THIS PAPER : Anisa and Geeta (2017). Performance testing of the rotary paddy weeder with different angle of blade. Internat. J. Agric. Engg., 10(1) : 86-91, DOI: 10.15740/HAS/IJAE/10.1/86-91. 